\title{
Preparation of Lassi from safflower milk blended with buffalo milk
}

\author{
V.S. MANE, S.G. NARWADE, R.P. KADAM AND A.T. SONTAKKE
}

\begin{abstract}
The present investigation was carried out to assess the suitability of safflower milk in preparation of Lassi. The preparation of Lassi from different properties of safflower milk and buffalo milk with addition of 16 per cent sugar of Lassi with different flavours was studied. It was observed that the Lassi prepared from 75 per cent safflower milk and 25 per cent buffalo milk with rose flavour was acceptable (8.2) scoring between like very much to like extremely. The rose flavour was found to be the most acceptable level.
\end{abstract}

KEY WORDS : Lassi, Safflower milk, Buffalo milk, Blend, Flavour

How To CITE THIS PAPER : Mane, V.S., Narwade, S.G., Kadam, R.P. and Sontakke, A.T. (2014). Preparation of Lassi from safflower milk blended with buffalo milk. Res. J. Animal Hus. \& Dairy Sci., 5(2) : 68-73.

Address for correspondence :

V.S. Mane, Department of Animal Husbandry and Dairy Science, College of Agriculture, Vasantrao Naik Marathwada Krishi Vidyapeeth, PARBHANI (M.S.) INDIA

Associated Authors' :

S.G. Narwade and A.T. Sontakke, Department of Animal Husbandry and Dairy Science, College of Agriculture, Vasantrao Naik Marathwada Krishi Vidyapeeth, PARBHANI (M.S.) INDIA

R.P. Kadam, Department of Extension Education, College of Agriculture, Vasantrao Naik Marathwada Krishi Vidyapeeth, PARBHANI (M.S.) INDIA 